Article

\title{
Investigating the Effect of Fruit Size on Ripening Recovery of Banana Treated with 1-Methylcyclopropene
}

\author{
Thabiso Kenneth Satekge ${ }^{1, *}$ and Lembe Samukelo Magwaza $1,2, *$ (D) \\ 1 Discipline of Horticultural Sciences, School of Agricultural and Earth and Environmental Science, \\ University of KwaZulu-Natal, Private Bag X01, Scottsville, Pietermaritzburg 3209, South Africa \\ 2 Discipline of Crop Science, School of Agricultural and Earth and Environmental Science, \\ University of KwaZulu-Natal, Private Bag X01, Scottsville, Pietermaritzburg 3209, South Africa \\ * Correspondence: satekgetk@gmail.com (T.K.S.); Magwazal@ukzn.ac.za (L.S.M.); \\ Tel.: +27-72-670-8413 (L.S.M.)
}

Citation: Satekge, T.K.; Magwaza, L.S. Investigating the Effect of Fruit Size on Ripening Recovery of Banana Treated with 1-Methylcyclopropene. Horticulturae 2021, 7, 357. https:/ / doi.org/10.3390/horticulturae7100357

Academic Editor: Elazar Fallik

Received: 9 June 2021

Accepted: 5 July 2021

Published: 3 October 2021

Publisher's Note: MDPI stays neutral with regard to jurisdictional claims in published maps and institutional affiliations.

Copyright: (c) 2021 by the authors. Licensee MDPI, Basel, Switzerland. This article is an open access article distributed under the terms and conditions of the Creative Commons Attribution (CC BY) license (https:// creativecommons.org/licenses/by/ $4.0 /)$.

\begin{abstract}
Postharvest application of 1-methylcycloprepene (1-MCP) on banana fruit to extend shelflife and maintain quality is inconsistent as treated fruit do not ripen uniformly. Banana response to 1-MCP treatment can be variable due to within-bunch variation in fruit size, composition, and maturity. Therefore, the present study investigated whether fruit size variation explains variability in ripening recovery. To investigate this relationship, large, medium, and small fruit were treated with $0 \mathrm{~nL} \mathrm{~L}^{-1}$ 1-MCP (control), $400 \mathrm{~nL} \mathrm{~L}^{-1} 1$-MCP and $50 \mu \mathrm{L} \mathrm{L}^{-1}$ ethephon $+400 \mathrm{~nL} \mathrm{~L}^{-1} 1$-MCP. Fruit were then ripened using $800 \mu \mathrm{L} \mathrm{L}^{-1}$ ethephon and stored at $23{ }^{\circ} \mathrm{C}$ for $30 \mathrm{~d}$. Irrespective of fruit size, treating banana with 1-MCP and ethephon + 1-MCP prolonged shelf-life by $30 \mathrm{~d}$ compared to control, which were fully ripe at $15 \mathrm{~d}$ for medium and large fruit, and $20 \mathrm{~d}$ for small fruit. 1-MCP significantly delayed yellow colour development (colour stage 4$)$, chlorophyll degradation $(97.4 \mu \mathrm{g} / \mathrm{g}$ ), and sucrose $(2.57 \mathrm{mg} / \mathrm{g})$ and glucose $(0.86 \mathrm{mg} / \mathrm{g})$ accumulation in small compared to medium and large fruit. However, firmness $(56.13 \mathrm{~N})$ and starch $(0.68 \mathrm{mg} / \mathrm{g})$ were significantly lower in 1-MCP-treated small-sized fruit compared to medium and large fruit. Moisture loss was also significantly higher $(19.49 \%)$ in 1-MCP-treated small fruit compared to medium $(14.89 \%)$ and large $(18.11 \%)$. Combined ethephon and 1-MCP allowed for an increase in ripening in small, medium, and large fruit. Overall, medium and large fruit treated with 1-MCP and ethephon + 1-MCP recovered their ripening capacity better compared to small fruit. The results demonstrate that 1-MCP efficacy is influenced by fruit size, whereas ethephon + 1-MCP treatment was consistent across small, medium, and large fruit. The effect of fruit size on 1-MCP efficacy might explain the inconsistency of the treatment in the banana fruit. Therefore, it is important to apply 1-MCP on fruit of approximately the same size to achieve the full benefit of the treatment. Moreover, fruit treated with 1-MCP + ethephon recovered their ripening capacity, irrespective of size, suggesting that it is a beneficial treatment.
\end{abstract}

Keywords: 1-MCP; banana fruit; banana starch; postharvest treatment; ripening capacity

\section{Introduction}

Banana (Musa acuminata) is a tropical and sub-tropical fruit that is increasingly consumed worldwide due to its nutritional properties, including higher vitamins, minerals, and polyphenols in the pulp, which help in the reduction in various diseases [1]. Banana pulp also contains higher concentrations of starch. Starch accumulates during fruit growth and development and degrades at the later stage of ripening [2,3]. Its degradation leads to an increase in fruit sweetness due to higher soluble solids [2,4,5]. Starch also plays an important role as a source of energy for metabolic processes including ripening (peel colour change, pulp softening, etc.) [2]. However, starch concentration was reported to be influenced by fruit size in banana and the differences were pronounced within a bunch [3].

Fruit located at the top of the bunch (basal) are large, have a greater cell number and accumulate more assimilates compared to those at the bottom (distal) during growth and 
development $[3,6]$. However, at harvest starch concentration in large- and small-sized fruit did not differ [3]. There is limited information linking starch concentration at harvest to postharvest ripening of banana fruit.

Banana is a typical climacteric fruit that continues to ripen after harvest. The fruit is highly perishable, with short shelf-life and rapid quality loss at ambient temperature. Various postharvest treatments, including the application of ethylene antagonist 1-methylcyclopropene (1-MCP), have been reported to delay ripening in fruits [7]. 1-MCP delays fruit ripening by binding on the ethylene receptors, thus antagonising the ripeningrelated phytohormone, ethylene [8,9]. The treatment is effective in delaying banana fruit ripening for the long-term. However, improper ripening, especially uneven peel colour, was reported to be associated with 1-MCP treatment, which affected fruit quality [10-12]. Therefore, for its commercial application, it is important to understand fruit response to 1-MCP treatment. Despite 1-MCP being efficacious in prolonging banana shelf-life, limited work has been carried out to investigate pre- or postharvest factors that induce uneven ripening in 1-MCP-treated banana.

Shelf-life of banana was more prolonged in large fruit treated with 1-MCP than in small fruit and this response was attributed to maturity [13]. Small fruit was immature to respond to 1-MCP, compared to large fruit [13]. However, Harris et al. [14] found that fruit within a bunch (hands) did not affect 1-MCP efficacy; instead, bunches of different maturities responded differently to 1-MCP treatment. Although it is unclear whether size affects banana fruit response to 1-MCP, these studies suggested that the effectiveness of $1-\mathrm{MCP}$ to prolong shelf-life and maintain good quality depends on maturity. This was also reported in avocado [15] and pear [16,17]. Since 1-MCP prolongs fruit shelf-life by binding ethylene receptors, immature (small) fruit may have fewer receptors and lack of response may be due to receptors developing after treatment application. Factors such as fruit size could affect 1-MCP response and thus lead to uneven ripening post treatment, since it has been reported that fruit of different sizes within banana bunch differ in maturity [3]. Smaller fruit located at a lower position of the bunch are less mature compared to those at the top or middle [3]. It was suggested that ripening recovery in banana fruit post 1-MCP treatment may be due to receptor regeneration or incomplete binding [18]. However, in kiwifruit, maturity did not affect 1-MCP response [19]. In banana fruit, there are generally no clear maturity indices; colour and firmness (angularity) are used to establish harvest date. Despite having fruit of different maturity [3], the whole bunch is harvested, and fruit are sorted according to size. This suggests that banana consignments would contain fruit of different maturity, resulting in uneven ripening recovery [14]. This inconsistent response limits the commercial application of 1-MCP on banana fruit $[14,18]$. Fruit response to 1-MCP treatment may be size dependent, especially because fruit of different sizes differ in important components such as dry matter and starch concentration, suggesting that recommended the 1-MCP concentration for banana may be too high or low depending on fruit size. Large fruit may have high energy (starch) that would allow it to recover ripening better post 1-MCP treatment, compared to small fruit.

Therefore, it is important to understand whether size affects fruit response to 1-MCP. This would ensure that the optimum concentration of 1-MCP for banana fruit is established based on fruit size. The present study, therefore, investigated the effect of size on 1-MCP efficacy in banana fruit. The study also investigated whether fruit of different sizes differ in dry matter and starch concentration and whether this difference explains the variability or uneven ripening recovery in 1-MCP-treated banana fruit post treatment.

\section{Materials and Methods}

\subsection{Plant Materials}

Green banana (cv. Williams) fruit were harvested from ND Globe Farm, a commercial plantation at Upper Tongaat, KwaZulu-Natal Province, South Africa $\left(29^{\circ} 24^{\prime} 32^{\prime \prime}\right.$ S, $31^{\circ} 2^{\prime} 23^{\prime \prime} \mathrm{W}$ ) during the 2020 season. After harvest, fruit were transported in a wellventilated vehicle to the Postharvest Laboratory at the University of KwaZulu-Natal, 
Pietermaritzburg, arriving within $2 \mathrm{~h}$. Upon arrival, fruit were equilibrated at $14{ }^{\circ} \mathrm{C}$ for $16 \mathrm{~h}$.

\subsection{Postharvest Treatments, Storage, and Sampling}

Fruit were grouped according to different sizes. Sizes were large, medium, and small, which were located at the top, middle, and lower position of the bunch, respectively (Table 1). Thereafter, fruit were packed into cardboard boxes and replicated four times (seven fruit per replicate and 28 per treatment). Within each group, fruit were treated with $0 \mathrm{~nL} \mathrm{~L}^{-1}$ 1-MCP (control), $400 \mathrm{~nL} \mathrm{~L}^{-1} 1-\mathrm{MCP}$ alone, and $50 \mu \mathrm{L} \mathrm{L}^{-1}$ ethephon followed by $400 \mathrm{~nL} \mathrm{~L}^{-1}$ 1-MCP (ethephon + 1-MCP). Fruit were immersed in ethephon treatment for $5 \mathrm{~min}$, followed by 1-MCP concentration exposure for $16 \mathrm{~h}$ (in 100-L sealed plastic drum) at $14{ }^{\circ} \mathrm{C}$. The experiment was arranged in a $3 \times 3 \times 4$ factorial under completely randomised design (CRD) with four replicates for each treatment factor. The 1-MCP powder required to make $400 \mathrm{~nL} \mathrm{~L}^{-1}$ was calculated according to the manufacturer's instruction. After respective treatment application, fruit were stored at ambient temperature $\left(23^{\circ} \mathrm{C}\right)$ for $5 \mathrm{~d}$ until immersed in $800 \mu \mathrm{L} \mathrm{L}^{-1}$ ethephon for $5 \mathrm{~min}$ to initiate ripening (Zhu et al., 2015) and left at shelf-life condition $\left(23^{\circ} \mathrm{C}\right)$ until $30 \mathrm{~d}$. Physico-chemical parameters were measured at 0 and $10 \mathrm{~d}$ intervals during the $30 \mathrm{~d}$ shelf-life. Seven fruit per replicate in a treatment were used for non-destructive assay (firmness, colour, and mass), whilst 3 fruit were used for destructive assay (chlorophyll, carotenoids, starch, non-structural carbohydrates, and starch granules) during shelf-life.

Table 1. Effect of banana fruit size on maturity parameters.

\begin{tabular}{|c|c|c|c|}
\hline \multirow[b]{2}{*}{ Parameters } & \multicolumn{3}{|c|}{ Fruit Size } \\
\hline & Small & Medium & Large \\
\hline Colour index ${ }^{a}$ & ns & ns & ns \\
\hline Hue $^{\mathrm{a}}$ & $117.5 \pm 0.24^{\mathrm{a}}$ & $117.8 \pm 0.21^{\mathrm{a}, \mathrm{b}}$ & $118.06 \pm 0.23^{b}$ \\
\hline Lightness $\left(\mathrm{L}^{*}\right)^{\mathrm{a}}$ & $54.29 \pm 0.47^{\mathrm{a}}$ & $56.07 \pm 0.53^{b}$ & $54.74 \pm 0.55^{\mathrm{a}}$ \\
\hline Total chlorophyll $(\mu \mathrm{g} / \mathrm{g})^{\mathrm{a}}$ & $578.1 \pm 0.22^{c}$ & $397.9 \pm 0.16^{b}$ & $302.7 \pm 0.27^{\mathrm{a}}$ \\
\hline Total carotenoids $(\mu \mathrm{g} / \mathrm{g})^{\mathrm{a}}$ & $195.8 \pm 0.07^{\mathrm{c}}$ & $126.0 \pm 0.02^{b}$ & $110.8 \pm 0.06^{\mathrm{a}}$ \\
\hline Firmness $(\mathrm{N})^{\mathrm{b}}$ & $80.56 \pm 0.55^{a}$ & $81.87 \pm 0.27^{b}$ & $80.84 \pm 0.52^{\mathrm{a}}$ \\
\hline Width $(\mathrm{mm})^{b}$ & $38.07 \pm 1.70^{\mathrm{a}}$ & $44.23 \pm 0.28^{b}$ & $45.01 \pm 0.48^{b}$ \\
\hline Length $(\mathrm{mm})^{\mathrm{b}}$ & $131.6 \pm 3.84^{\mathrm{a}}$ & $154.6 \pm 0.18^{b}$ & $160.0 \pm 0.91^{c}$ \\
\hline Fresh mass $(\mathrm{g})^{\mathrm{b}}$ & $157.5 \pm 3.87^{\mathrm{a}}$ & $202.6 \pm 3.59^{b}$ & $258.2 \pm 6.25^{c}$ \\
\hline Dry matter ${ }^{\mathrm{C}}$ & ns & ns & ns \\
\hline Sucrose $(\mathrm{mg} / \mathrm{g})^{\mathrm{c}}$ & $0.21 \pm 0.01^{\mathrm{a}}$ & $0.45 \pm 0.01^{\mathrm{c}}$ & $0.32 \pm 0.01^{b}$ \\
\hline Starch $(\mathrm{mg} / \mathrm{g})^{\mathrm{c}}$ & $8.10 \pm 0.01^{b}$ & $9.15 \pm 0.00^{\mathrm{c}}$ & $5.65 \pm 0.20^{\mathrm{a}}$ \\
\hline Starch granule length $(\mathrm{mm})^{\mathrm{c}}$ & ns & ns & ns \\
\hline Starch granule width $(\mathrm{mm})^{\mathrm{c}}$ & ns & ns & ns \\
\hline
\end{tabular}

Values followed by different letters $(\mathrm{a}-\mathrm{c})$ within a row are significant according to least significant difference (LSD) at $p \propto 0.05$. ns; not significant according to ANOVA. ${ }^{a}$ Measurements were made on the peel; ${ }^{b}$ Measurements were of the whole fruit; ${ }^{c}$ Analyses were made using pulp powder.

\subsection{Determination of Peel Colour and Colour Index}

A total of 7 fruit per replicate were used to evaluate peel colour based on the colour chart. Dole ${ }^{\circledR}$ banana colour chart (Dole Food Company, Inc., Westlake Village, CA, USA) was used to rate peel colour based on a scale of 1 to 7 , where $1=$ all green, $2=$ light green, $3=$ half green and yellow, $4=$ more yellow than green, $5=$ yellow with green tips, $6=$ full yellow, and $7=$ yellow flecked with brown colour. Thereafter, the colour index was calculated using Equation (1):

$$
\sum=\frac{\text { Number of fruit in scale } \times \text { Scale value }}{\text { Total number of fruit evaluated }}
$$

Fruit peel colour was also determined by measuring the middle part of the fruit around the equatorial region at three points using a portable colourimeter (Chroma Meter, 
Konica Minolta Sensing Inc., Osaka, Japan) expressing CIELAB colour space; L*, a ${ }^{*}$, and $b^{*}$. Furthermore, the colour parameters chroma and hue angle were calculated using Equations (2) and (3), respectively.

$$
\begin{aligned}
& \mathrm{C}^{*}=\left(\mathrm{a}^{* 2}+\mathrm{b}^{* 2}\right)^{1 / 2} \\
& \mathrm{~h}^{\circ}=\tan ^{-1}\left(\frac{b^{*}}{a^{*}}\right)
\end{aligned}
$$

\subsection{Determination of Firmness and Mass Loss}

Fruit firmness was measured at $10 \mathrm{~d}$ intervals during shelf-life, using a hand-held firmness tester (Bareiss, Germany), and expressed as Newton (N). Fruit firmness was expressed as the mean of two readings taken at the equatorial region of the fruit on opposite sides and the results are expressed as Newton (N). Fruit mass was measured using a digital weighing balance (RADWAG Wagi Electronic Inc., Radom, Poland) and mass loss was calculated as a cumulative percentage (\%) loss in mass based on mass before storage and at the sampling time during storage. The mass loss was calculated using Equation (4) and expressed as \%.

$$
\text { Moisture loss (\%) }=\frac{\text { Initial mass }- \text { Final mass }}{\text { Initial mass }} \times 100 \%
$$

\subsection{Determination of Total Chlorophyll and Carotenoids}

The chlorophylls (Chls) and total carotenoids were extracted by immersing $0.2 \mathrm{~g}$ powder of peel tissue in $80 \%(v / v)$ ice-cold acetone $(4 \mathrm{~mL})$. After extraction in the dark for $1 \mathrm{~h}$, the extract was centrifuged at $20,000 \mathrm{rpm}$ for $10 \mathrm{~min}$ at $5^{\circ} \mathrm{C}$. The absorbance of the supernatant was read on UV-1800 Spectrophotometer (Shimadzu Scientific Instruments INC., Columbia, MD, USA) at 663.2, 646.8, and $420 \mathrm{~nm}$ wavelengths for chlorophyll a, chlorophyll $b$, and total carotenoids, respectively. Thereafter, Equations (5)-(8) were used to calculate $\mathrm{Chl}_{\mathrm{a}}, \mathrm{Ch}_{\mathrm{b}}$, total chlorophyll $\left(\mathrm{Chl}_{\mathrm{a}+\mathrm{b}}\right)$, and carotenoids $\left(\mathrm{C}_{\mathrm{x}+\mathrm{c}}\right)$, respectively [20]. Total chlorophyll and carotenoids were expressed as $\mu \mathrm{g} / \mathrm{g}$ on a dry mass basis.

$$
\begin{gathered}
\mathrm{Chl}_{\mathrm{a}}=12.25 \mathrm{~A}_{663.2}-2.79 \mathrm{~A}_{646.8} \\
\mathrm{Ch}_{\mathrm{b}}=21.50 \mathrm{~A}_{646.8}-5.10 \mathrm{~A}_{663.2} \\
\text { Total chlorophyll }{ }_{(\mathrm{Chla}+\mathrm{b})=} \mathrm{Chl}_{\mathrm{a}}+\mathrm{Chl}_{\mathrm{b}} \\
\text { Total carotenoids }{ }_{(\mathrm{Cx}+\mathrm{c})}=\left(1000 \mathrm{~A}_{470}-1.82 \mathrm{Chl}_{\mathrm{a}}-85.02 \mathrm{Chl}_{\mathrm{b}}\right) / 198
\end{gathered}
$$

\subsection{Determination of Pulp Starch}

Starch concentration was extracted and quantified using a method described by Lo'ay and El-Khateeb [21] with modification. Briefly, $0.2 \mathrm{~g}$ freeze-dried pulp powder was immersed in $10 \mathrm{~mL}$ of $80 \%(v / v)$ ethanol. The samples were placed in a water bath at $80^{\circ} \mathrm{C}$ for $1 \mathrm{~h}$, and left overnight to cool at $4{ }^{\circ} \mathrm{C}$. The supernatant was discarded, and the residue was washed twice using $5 \mathrm{~mL}$ of $80 \%$ ethanol at $80^{\circ} \mathrm{C}$ water bath to completely rid soluble sugars. The residue was then dried in Genvac evaporator (Genvac ${ }^{\circledR}$ EZ 2.3; IPSWICH; England) at $70^{\circ} \mathrm{C}$ for $3 \mathrm{~h}$. Thereafter, the dried residue was dissolved with $10 \mathrm{~mL}$ of $0.25 \mathrm{M}$ sulfuric acid at $100^{\circ} \mathrm{C}$ for $1 \mathrm{~h}$. The solution was centrifuged at $20,000 \mathrm{rpm}$ for $10 \mathrm{~min}$ at $5{ }^{\circ} \mathrm{C}$; thereafter, the supernatant was filtered through Whatman No. 1 filter paper to obtain a clear extract. The extract $(0.4 \mathrm{~mL})$ was then mixed with freshly prepared $0.4 \mathrm{~mL}$ sulfuric acid-anthrone reagent $(100 \mathrm{mg}$ anthrone in $100 \mathrm{~mL}$ of ice-cold $76 \%$ sulfuric acid). The mixture was then heated for $10 \mathrm{~min}$ at $100{ }^{\circ} \mathrm{C}$ in a water bath. The samples were cooled at room temperature, and the absorbance was determined at $620 \mathrm{~nm}$ using a UV-1800 Spectrophotometer (Shimadzu Scientific Instruments INC., Columbia, MD, USA), against blank (anthrone-sulfuric acid reagent). A standard curve was plotted using glucose 
(0-300 mg/mL, $\left.\mathrm{R}^{2}=0.95\right)$ and starch concentration was determined by multiplying glucose concentration found in samples by factor 0.9 and expressed as $\mathrm{mg} / \mathrm{g}$ on a dry mass basis.

\subsection{Determination of Pulp Sucrose, Fructose, and Glucose}

Non-structural carbohydrates were extracted and quantified using the methodology described by Ncama et al. [22] with modification [10]. Briefly, non-structural carbohydrates were extracted using $80 \%(v / v)$ ethanol. Concentrations of glucose, fructose, and sucrose were quantified using the HLPC binary pump (Shimadzu Scientific Instruments INC., Columbia, MD, USA), equipped with refractive index detector and Rezex RCM monosaccharide $\mathrm{CA}^{+}(8 \%)$ column (Phenomenex, Torrance, CA, USA). Ultra-pure water was used as a mobile phase and column temperature was $85^{\circ} \mathrm{C}$ (thermo-stated column compartment; G1316A, Shimadzu Scientific Instruments INC., Columbia, MD, USA). The presence and concentration of individual sugars were calculated by comparing the peak area of samples against those of known fructose $\left(0-2.5 \mathrm{mg} / \mathrm{mL} ; \mathrm{R}^{2}=0.99\right)$, glucose $\left(0-2.5 \mathrm{mg} / \mathrm{mL} ; \mathrm{R}^{2}=0.99\right)$, and sucrose $\left(0-2.5 \mathrm{mg} / \mathrm{mL} ; \mathrm{R}^{2}=0.99\right)$ standard concentration curves and expressed in $\mathrm{mg} / \mathrm{g}$ on a dry mass basis.

\subsection{Morphology of the Starch Granules}

A freeze-dried pulp powder was sieved using $90 \mu \mathrm{m}$ stainless steel star screen sieve mesh. Thereafter, samples were fixed on brown stubs using double-sided aluminium tape and coated with gold three times (Ion Sputter Coater, Eiko IB-3, Ibaraki, Japan) to improve electrical conductivity. Thereafter, coated samples were taken to a Scanning Electron Microscope (SEM) (Zeiss Evo LS 15) for starch granules viewing at $1500 \times$ magnification, operating under full vacuum.

\subsection{Statistical Analysis}

Experimental data were statistically analysed using three-way ANOVA considering fruit size, 1-MCP treatments, and shelf-life duration, and their interactions, as the source of variance. Duncan Multiple Range (DMRT) was used to test significant differences among treatment means at $p \leq 0.05$. All the analyses were performed using GenStat statistical software (GenStat ${ }^{\circledR}, 18$ th edition, VSN International, Hemel Hempstead, UK).

\section{Results}

\subsection{Maturity Parameters at Harvest}

Table 1 indicates the banana fruit maturity index or parameters at harvest. At harvest, all fruit of different sizes were green, colour stage 1, although hue ${ }^{\circ}$ was slightly higher in large (118.06) compared to small (117.5) and medium (117.8) fruit. Total chlorophyll was significantly higher in small $(578.1 \mu \mathrm{g} / \mathrm{g})$ compared to medium $(397.9 \mu \mathrm{g} / \mathrm{g})$ and large $(302.7 \mu \mathrm{g} / \mathrm{g})$ fruit. At harvest, large fruit had significantly lower total chlorophyll compared to small and large. Fruit firmness was significantly higher in medium (81.87 N) compared to small $(80.56 \mathrm{~N})$ and large $(80.84 \mathrm{~N})$ fruit. Large fruit had a fresh mass of $258.2 \mathrm{~g}$, significantly $(p<0.001)$ higher than in small $(157.5 \mathrm{~g})$ and medium $(202.6 \mathrm{~g})$. However, medium fruit had a significantly higher starch concentration $(9.12 \mathrm{mg} / \mathrm{g})$ compared to small $(8.10 \mathrm{mg} / \mathrm{g})$ and large $(5.65 \mathrm{mg} / \mathrm{g})$. Similarly, medium fruit had a significantly higher sucrose concentration $(0.45 \mathrm{mg} / \mathrm{g})$ compared to small $(0.21 \mathrm{mg} / \mathrm{g})$ and large $(0.32 \mathrm{mg} / \mathrm{g})$. Dry matter did not differ significantly among small, medium, and large fruit at harvest. The length and width of starch granules were not significantly different across fruit of different sizes. Starch granules were smooth-surfaced and presented an oval and elongated shape in fruit of all sizes. In addition, a small number of big, rounded granules were observed in small fruit, compared to medium and large fruit. However, granules in small-sized fruit were more intact compared to medium and large fruit at harvest. 


\subsection{Effect of Fruit Size and 1-MCP on Peel Colour Change}

Banana peel colour change was affected significantly $(p<0.001)$ by fruit size, $1-\mathrm{MCP}$ treatments, and storage duration. Control medium and large fruit turned yellow with trace green colour (colour stage 4 ) at $10 \mathrm{~d}$, whilst small fruit were at colour stage three. In addition, medium- and large-sized fruit were completely yellow with flecked brown spots at $15 \mathrm{~d}$ (data not shown), and small-sized fruit were completely yellow with flecked brown spots at $20 \mathrm{~d}$. Fruit of all sizes treated with 1-MCP and ethephon +1-MCP were green at day 10 (colour stage 2). 1-MCP-treated large- and medium sized fruit turned significantly yellow (from colour stage 5 to 7 ) compared to small fruit from 20 up to $30 \mathrm{~d}$. 1-MCP-treated small fruit reached colour stage 5 at $30 \mathrm{~d}$. Fruit treated with ethephon +1-MCP followed the same trend as 1-MCP-treated fruit, with small fruit reaching colour seven (Figure 1).

Hue values of control large fruit were significantly $(p<0.001)$ higher $(101.46)$ compared to small (99.01) and medium (100.52) from $10 \mathrm{~d}$ shelf-life (Figure 1). 1-MCP-treated fruit had significantly higher values in small-sized (97. 20 and 85.47) compared to medium (94.17 and 83.21) and large-sized (92.63 and 83.53) fruit, from 20 to $30 \mathrm{~d}$, respectively. The same trend was observed in ethephon +1-MCP-treated fruit. On average, hue values were higher in small fruit than in medium and large fruit and 1-MCP than in ethephon + 1-MCP-treated fruit.

\subsection{Effect of Fruit Size and 1-MCP on Total Chlorophyll and Carotenoids}

Chlorophyll degradation was affected by fruit size and 1-MCP-treatments. At day 10, total chlorophyll was significantly $(p<0.001)$ higher in large-sized $(277.1 \mu \mathrm{g} / \mathrm{g})$ compared to small $(69.6 \mu \mathrm{g} / \mathrm{g})$ and medium $(54.9 \mu \mathrm{g} / \mathrm{g})$ fruit. Control medium fruit had significantly lower chlorophyll compared to small fruit. At $20 \mathrm{~d}$ shelf-life, large fruit treated with ethephon + 1-MCP had higher $(153.7 \mu \mathrm{g} / \mathrm{g})$ chlorophyll compared to small $(80.2 \mu \mathrm{g} / \mathrm{g})$ and medium $(19.4 \mu \mathrm{g} / \mathrm{g})$ fruit treated with ethephon + 1-MCP and fruit of all sizes treated with 1-MCP (97.4, 75.4, and $71.3 \mu \mathrm{g} / \mathrm{g}$, for small, medium, and large fruit, respectively). Medium fruit treated with ethephon +1-MCP had significantly lower chlorophyll (Figure 2).

The effect on 1-MCP and fruit size was significant $(p<0.001)$ during shelf-life. Total carotenoids in control medium fruit were significantly higher $(76.2 \mu \mathrm{g} / \mathrm{g})$ than in small $(63.3 \mu \mathrm{g} / \mathrm{g})$ and large $(59.3 \mu \mathrm{g} / \mathrm{g})$ fruit at $10 \mathrm{~d}$ shelf-life. In addition, at $20 \mathrm{~d}$ total carotenoids in small control fruit was $48.6 \mu \mathrm{g} / \mathrm{g}$. Small fruit treated with 1-MCP had higher total carotenoids $(117.4 \mu \mathrm{g} / \mathrm{g})$ compared to medium $(98.9 \mu \mathrm{g} / \mathrm{g})$ and large $(91.2 \mu \mathrm{g} / \mathrm{g})$ fruit at $20 \mathrm{~d}$. Regarding ethephon $+1-\mathrm{MCP}$, large fruit had significantly higher total carotenoids $(96 \mu \mathrm{g} / \mathrm{g})$ compared to small $(86.3 \mu \mathrm{g} / \mathrm{g})$ and medium $(58 \mu \mathrm{g} / \mathrm{g})$ fruit (Figure 2).

\subsection{Effect of Fruit Size and 1-MCP on Fruit Firmness}

Firmness change during shelf-life duration was affected significantly $(p<0.001)$ by fruit size and 1-MCP treatments. Control small fruit had significantly lower firmness $(66.66 \mathrm{~N})$ compared to the large $(69.58 \mathrm{~N})$ and medium $(69.53 \mathrm{~N})$ fruit, which did not differ at $10 \mathrm{~d}$. In 1-MCP-treated fruit, firmness decreased significantly more after $10 \mathrm{~d}$, up to $30 \mathrm{~d}$, in small fruit $(80.94$ to $56.13 \mathrm{~N})$ compared to medium $(80.75$ to $58.78 \mathrm{~N})$ and large $(80.84$ to $59.31 \mathrm{~N})$ fruit. In ethephon + 1-MCP, firmness decreased significantly more in medium (79.22 to $52.39 \mathrm{~N})$, compared to small (77.63 to $60.75 \mathrm{~N}$ ) and large (77.56 to $56.51 \mathrm{~N})$ fruit from 10 up to $30 \mathrm{~d}$ during shelf-life. On average, firmness was lower in ethephon + 1-MCP-treated fruit, especially in medium rather than in small and large, and higher in 1-MCP-treated fruit (medium- and large-sized fruit) (Figure 3). 


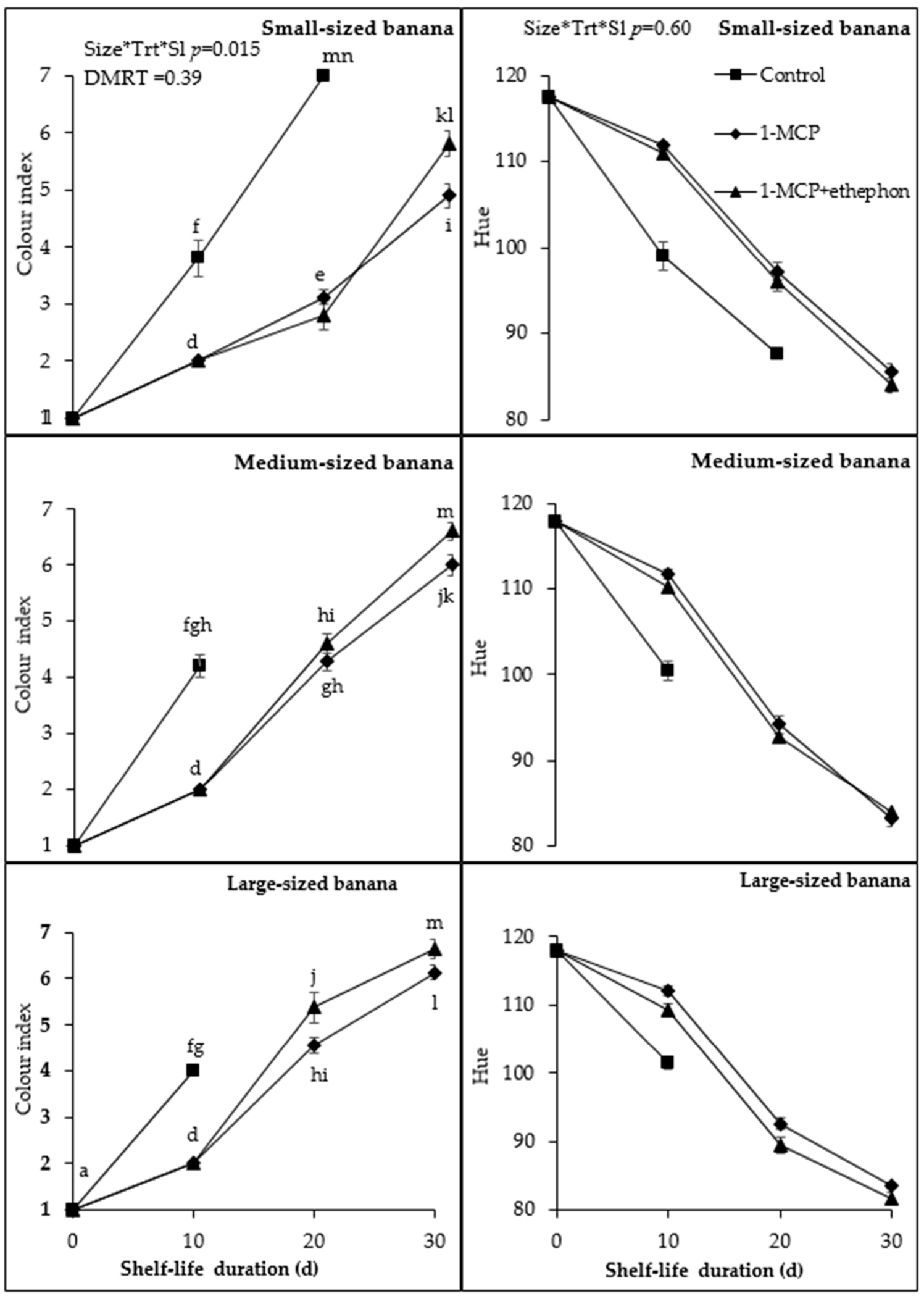

Figure 1. Effect of fruit size, 1-MCP treatments, and shelf-life and their interaction on peel colour index (left) and hue values (right) at ambient temperature. Size ${ }^{*} \mathrm{Trt}^{*} \mathrm{Sl}$ represents significant or non-significant interaction of fruit size, 1-MCP, and shelf-life duration at $p<0.05$ or $p>0.05$, respectively, according to Duncan Multiple Range Test (DMRT). Each value is a mean of four replicates $(n=4) \pm$ standard error. ${ }^{*}$ Control fruit were removed at $15 \mathrm{~d}$ after they were fully yellow, indicating that they were fully ripe. 

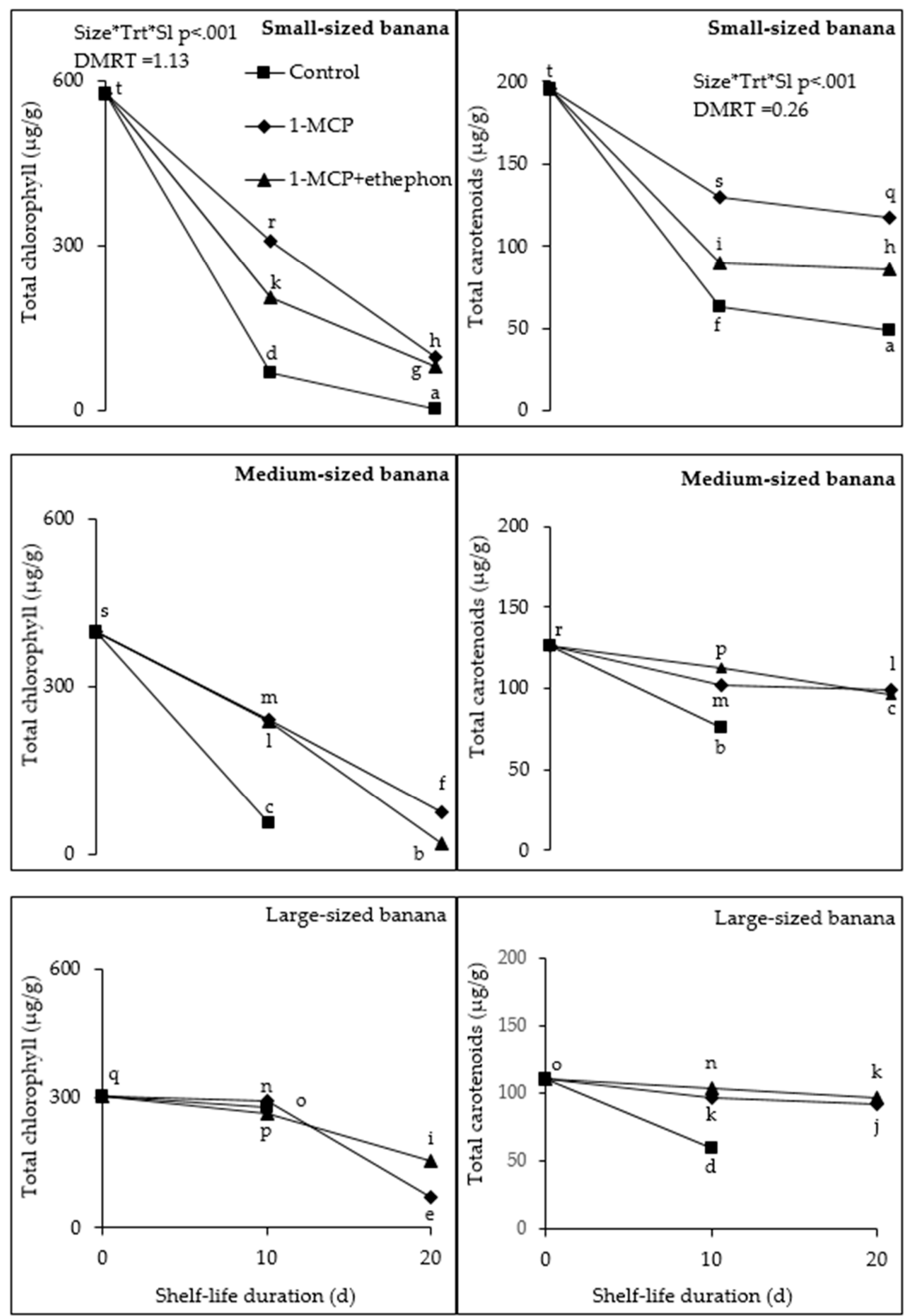

Figure 2. Effect of fruit size, 1-MCP, and shelf-life and their interaction on total chlorophyll (left column) and carotenoids (right column) at ambient temperature. Size ${ }^{*} \mathrm{Trt}^{*} \mathrm{Sl}$ represents significant interaction of fruit size, 1-MCP, and shelf-life duration at $p<0.05$ according to Duncan Multiple Range Test (DMRT). Each value is a mean of four replicates $(n=4) \pm$ standard error. Control fruit were removed at $15 \mathrm{~d}$ after they were fully yellow, indicating that they were fully ripe. 

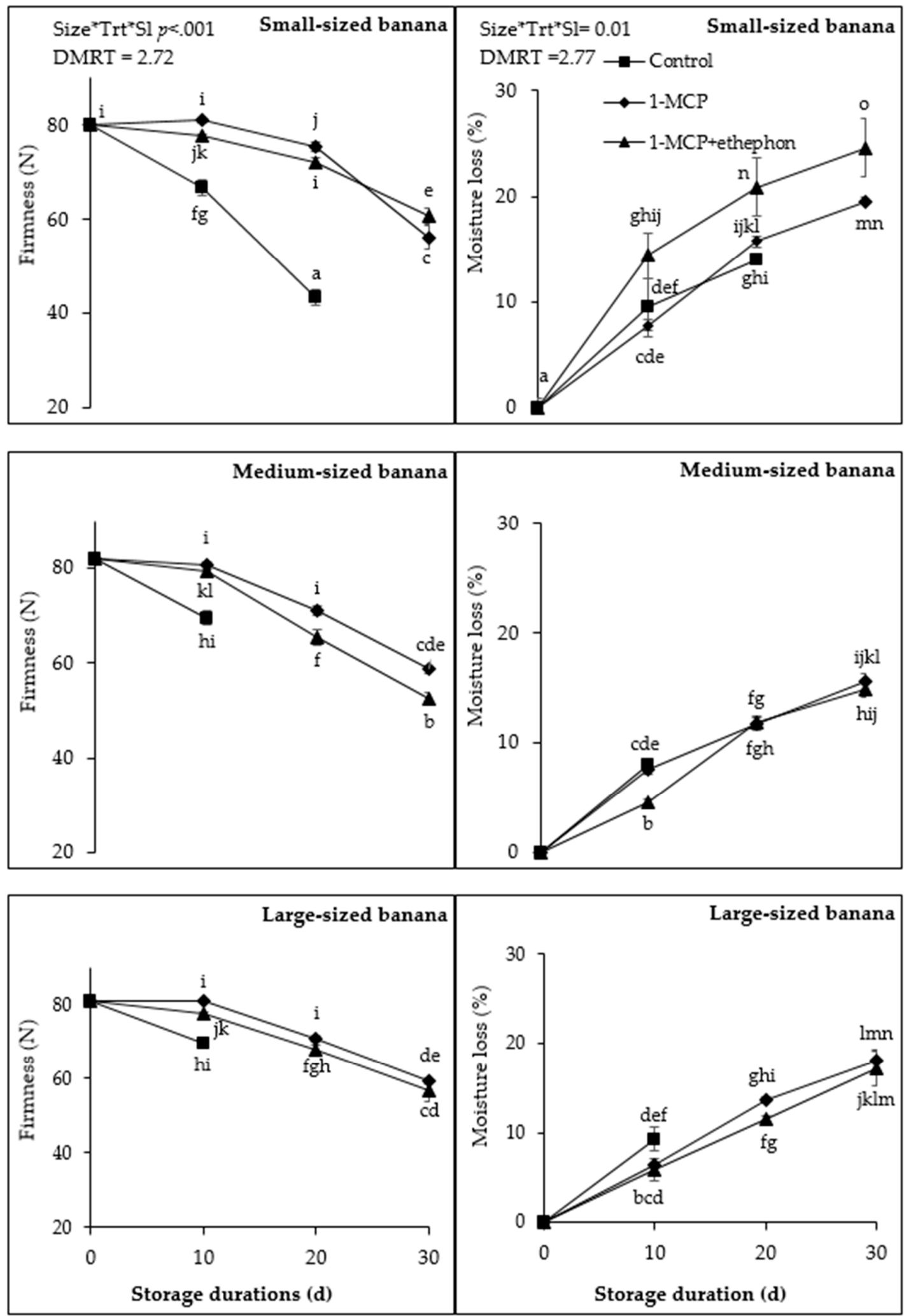

Figure 3. Effect of fruit size, 1-MCP treatments, and shelf-life and their interaction on firmness in Newton (N) (left column) and moisture loss in percentage (\%) (right column) at ambient temperature. Size ${ }^{*} \operatorname{Trt}^{*} \mathrm{Sl}$ represents significant interaction of fruit size, 1-MCP, and shelf-life duration at $p<0.05$ according to Duncan Multiple Range Test (DMRT). Each value is a mean of four replicates $(n=4) \pm$ standard error. Control fruit were removed at $15 \mathrm{~d}$ after they were fully yellow, indicating that they were fully ripe. 


\subsection{Effect of Fruit Size and 1-MCP on Moisture Loss}

Moisture loss was affected significantly $(p=0.008)$ by fruit size and 1-MCP treatment during $30 \mathrm{~d}$ shelf-life (Figure 3). In control fruit at $10 \mathrm{~d}$ shelf-life, small and large lost 9.44 and $9.29 \%$ moisture, respectively, significantly more compared to medium-sized fruit $(7.97 \%)$. However, treated fruit lost significantly less moisture compared to the control. After $30 \mathrm{~d}$ shelf-life, moisture loss was significantly higher in small fruit treated with ethephon + 1-MCP $(24.56 \%)$ compared to 1-MCP-treated fruit $(19.49 \%)$, large fruit treated with 1-MCP $(18.11 \%)$ and ethephon + 1-MCP $(17.15 \%)$, and medium fruit treated with 1-MCP (14.89) and ethephon + 1-MCP (15.59\%). On average, ethephon + 1-MCP-treated fruit lost significantly more moisture compared to 1-MCP. In addition, small-sized fruit lost more moisture compared to the medium and large fruit (Figure 3).

\subsection{Effect of Fruit Size and 1-MCP on Starch Concentration}

The concentrations of starch in the pulp of small, medium, and large fruit was affected significantly $(p<0.001)$ by 1-MCP treatments during shelf-life. Starch concentration decreased significantly from 8.10 to $0.25,9.42$ to 3.26 , and 5.65 to $0.08 \mathrm{mg} / \mathrm{g}$ in control small, medium, and large fruit, respectively, during shelf-life. In the case of 1-MCP-treated fruit, medium-sized fruit had significantly higher starch $(5.09 \mathrm{mg} / \mathrm{g})$ compared to small $(0.68 \mathrm{mg} / \mathrm{g})$ and large $(1.36 \mathrm{mg} / \mathrm{g})$ fruit at the end of $20 \mathrm{~d}$ shelf-life. In addition, ethephon + 1-MCP-treated medium fruit had a significantly higher starch $(4.82 \mathrm{mg} / \mathrm{g})$ concentration compared to small $(0.91 \mathrm{mg} / \mathrm{g})$ and large fruit $(0.56 \mathrm{mg} / \mathrm{g})($ Table 2$)$. On average, $1-\mathrm{MCP}-$ treated medium fruit had a significantly higher starch concentration compared to ethephon $+1-\mathrm{MCP}$, as well as small and large fruit treated with 1-MCP and ethephon + 1-MCP.

Table 2. Effect of fruit size, 1-MCP treatments, and shelf-life and their interaction on starch concentration during shelf-life at ambient temperature.

\begin{tabular}{|c|c|c|c|c|c|c|c|c|}
\hline \multirow[t]{2}{*}{ Fruit Size } & \multirow[t]{2}{*}{ Treatment } & \multicolumn{2}{|c|}{ Shelf-Life Duration (d) } & \multicolumn{5}{|c|}{ Significance $p \alpha 0.05$} \\
\hline & & 0 & 10 & 20 & Size & Trt & S1 & $S^{*} \operatorname{Trt}^{*} \mathrm{Sl}$ \\
\hline \multirow[t]{3}{*}{ Small } & Control & $8.10 \pm 0.01^{t}$ & $5.42 \pm 0.00 \mathrm{q}$ & $0.25 \pm 0.04^{b}$ & $<0.001$ & $<0.001$ & $<0.001$ & $<0.001$ \\
\hline & 1-MCP & $8.10 \pm 0.01^{\mathrm{t}}$ & $6.14 \pm 0.01^{\mathrm{s}}$ & $0.68 \pm 0.00^{\mathrm{d}}$ & & & & \\
\hline & $\begin{array}{l}\text { 1-MCP + } \\
\text { ethephon }\end{array}$ & $8.10 \pm 0.01^{\mathrm{t}}$ & $1.14 \pm 0.00^{f}$ & $0.91 \pm 0.01^{\mathrm{e}}$ & & & & \\
\hline \multirow[t]{3}{*}{ Medium } & Control & $9.15 \pm 0.00^{\mathrm{u}}$ & $3.26 \pm 0.04^{j}$ & $*$ & & & & \\
\hline & 1-MCP & $9.15 \pm 0.00^{\mathrm{u}}$ & $4.04 \pm 0.02 \mathrm{~m}$ & $5.09 \pm 0.02 \mathrm{p}$ & & & & \\
\hline & $\begin{array}{l}\text { 1-MCP + } \\
\text { ethephon }\end{array}$ & $9.15 \pm 0.00^{\mathrm{u}}$ & $4.34 \pm 0.01^{\mathrm{n}}$ & $4.82 \pm 0.03^{\circ}$ & & & & \\
\hline \multirow[t]{3}{*}{ Large } & Control & $5.65 \pm 0.02^{r}$ & $0.08 \pm 0.00^{\mathrm{a}}$ & $*$ & & & & \\
\hline & 1-MCP & $5.65 \pm 0.02^{\mathrm{r}}$ & $1.31 \pm 0.02^{h}$ & $1.36 \pm 0.01^{\mathrm{i}}$ & & & & \\
\hline & $\begin{array}{l}\text { 1-MCP + } \\
\text { ethephon }\end{array}$ & $5.65 \pm 0.02^{r}$ & $1.18 \pm 0.04 \mathrm{~g}$ & $0.56 \pm 0.02^{c}$ & & & & \\
\hline
\end{tabular}

Means with the different letter (s) within a row and column were significantly different by Duncan Multiple Range test at $p \alpha 0.05$. Each value is a mean of four replicates $(n=4) \pm$ standard error. * Control fruit were removed after they reached colour stage 7 (fully yellow) which indicated that they were fully ripe.

\subsection{Effect of Fruit Size and 1-MCP on Sucrose, Glucose, and Fructose Concentration}

Soluble sugars accumulation during shelf-life was significantly $(p<0.001)$ affected by fruit size and 1-MCP treatments, with no effect on fructose $(p>0.05)$. In control small fruit, sucrose increased significantly from 0.29 to $3.89 \mathrm{mg} / \mathrm{g}$ compared to medium $(0.45$ to $3.53 \mathrm{mg} / \mathrm{g})$ and large $(0.32$ to $2.86 \mathrm{mg} / \mathrm{g})$ fruit. In 1-MCP-treated fruit, small fruit had significantly lower sucrose (2.24 to $2.57 \mathrm{mg} / \mathrm{g}$ ) compared to medium (4.24 to $3.87 \mathrm{mg} / \mathrm{g})$ and large (2.47 to $4.65 \mathrm{mg} / \mathrm{g}$ ) fruit from 20 up to $30 \mathrm{~d}$ shelf-life. As for ethephon + 1-MCP treated fruit, sucrose was significantly higher in small $(4.31 \mathrm{mg} / \mathrm{g})$ compared to medium $(2.66 \mathrm{mg} / \mathrm{g})$. In addition, large fruit had significantly higher sucrose $(3.69 \mathrm{mg} / \mathrm{g})$ compared to medium $(2.66 \mathrm{mg} / \mathrm{g})$. However, the differences in sucrose in small and large fruit were not significant (Table 3). 
Table 3. Effect of fruit size, 1-MCP, treatments and shelf-life duration and their interaction on sucrose, glucose, and fructose concentration at ambient temperature.

\begin{tabular}{|c|c|c|c|c|c|c|c|c|c|}
\hline \multirow[t]{2}{*}{ Fruit Size } & \multirow[t]{2}{*}{ Treatment } & \multicolumn{3}{|c|}{ Shelf-Life Duration (d) } & \multicolumn{5}{|c|}{ Significance $p \alpha 0.05$} \\
\hline & & 0 & 10 & 20 & 30 & Size & Trt & S1 & $S^{*} \operatorname{Trt}^{*} \mathrm{~S} 1$ \\
\hline \multirow{4}{*}{ Small } & & & $\begin{array}{l}\text { SUCROSE } \\
(\mathrm{mg} / \mathrm{g})\end{array}$ & & & $<0.001$ & $<0.001$ & $<0.001$ & $<0.001$ \\
\hline & Control & $0.21 \pm 0.01^{\mathrm{a}}$ & $0.55 \pm 0.01^{\mathrm{a}}$ & $3.89 \pm 0.77^{\mathrm{d}, \mathrm{e}}$ & \multirow{2}{*}{\multicolumn{2}{|c|}{${ }^{*} 2.57 \pm 0.37^{\mathrm{b}}$}} & & & \\
\hline & 1-MCP & $0.21 \pm 0.01^{\mathrm{a}}$ & $0.47 \pm 0.20^{\mathrm{a}}$ & $2.24 \pm 0.07^{\mathrm{b}}$ & & & & & \\
\hline & $\begin{array}{l}\text { 1-MCP + } \\
\text { ethephon }\end{array}$ & $0.21 \pm 0.01^{\mathrm{a}}$ & $0.65 \pm 0.03^{\mathrm{a}}$ & $2.73 \pm 0.52^{b}$ & \multicolumn{2}{|l|}{$4.31 \pm 0.10^{\mathrm{d}, \mathrm{e}}$} & & & \\
\hline \multirow[t]{2}{*}{ Medium } & Control & $0.45 \pm 0.01^{\mathrm{a}}$ & $3.53 \pm 0.11^{c, d}$ & $*$ & * & & & & \\
\hline & 1-MCP & $0.45 \pm 0.01^{\mathrm{a}}$ & $0.31 \pm 0.01^{\mathrm{a}}$ & $4.24 \pm 0.44^{\mathrm{d}, \mathrm{e}}$ & $3.87 \pm 0.46^{\mathrm{d}, \mathrm{e}}$ & & & & \\
\hline \multirow{3}{*}{ Large } & $\begin{array}{l}\text { 1-MCP + } \\
\text { ethephon }\end{array}$ & $0.45 \pm 0.01^{\mathrm{a}}$ & $0.38 \pm 0.03^{\mathrm{a}}$ & $2.03 \pm 0.61^{\mathrm{b}}$ & $2.66 \pm 0.24^{b}$ & & & & \\
\hline & Control & $0.32 \pm 0.01^{\mathrm{a}}$ & $2.86 \pm 0.44^{b, c}$ & $*$ & * & & & & \\
\hline & 1-MCP & $0.32 \pm 0.01^{\mathrm{a}}$ & $0.53 \pm 0.33^{\mathrm{a}}$ & $2.47 \pm 0.59^{b}$ & $4.65 \pm 0.14^{\mathrm{e}}$ & & & & \\
\hline \multirow{4}{*}{$\begin{array}{l}\text { GLUCOSE }(\mathrm{mg} / \mathrm{g}) \\
\text { Small }\end{array}$} & $\begin{array}{l}\text { 1-MCP + } \\
\text { ethephon }\end{array}$ & $0.32 \pm 0.01^{\mathrm{a}}$ & $0.44 \pm 0.06^{\mathrm{a}}$ & $2.49 \pm 0.12^{b}$ & $3.69 \pm 0.15^{\mathrm{d}}$ & & & & \\
\hline & $<0.001$ & $<0.001$ & $<0.001$ & 0.008 & & & & & \\
\hline & Control & $\mathrm{Nd}$ & $\mathrm{Nd}$ & $2.87 \pm 0.01^{\mathrm{i}, \mathrm{j}, \mathrm{k}}$ & * & & & & \\
\hline & 1-MCP & $\mathrm{Nd}$ & $\mathrm{Nd}$ & $0.40 \pm 0.01^{\mathrm{a}}$ & $0.86 \pm 0.12^{a, b}$ & & & & \\
\hline \multirow{3}{*}{ Medium } & $\begin{array}{l}\text { 1-MCP + } \\
\text { ethephon }\end{array}$ & $\mathrm{Nd}$ & $\mathrm{Nd}$ & $0.46 \pm 0.08^{a}$ & $1.55 \pm 0.04^{\mathrm{b}-\mathrm{f}}$ & & & & \\
\hline & Control & $\mathrm{Nd}$ & $1.26 \pm 0.02^{\mathrm{a}-\mathrm{e}}$ & $*$ & * & & & & \\
\hline & 1-MCP & $\mathrm{Nd}$ & $\mathrm{Nd}$ & $1.02 \pm 0.08^{a-d}$ & $1.11 \pm 0.12^{\mathrm{a}-\mathrm{d}}$ & & & & \\
\hline \multirow{3}{*}{ Large } & $\begin{array}{l}\text { 1-MCP + } \\
\text { ethephon }\end{array}$ & $\mathrm{Nd}$ & $\mathrm{Nd}$ & $1.06 \pm 0.04^{\mathrm{a}-\mathrm{d}}$ & $1.00 \pm 0.09^{\mathrm{a}-\mathrm{d}}$ & & & & \\
\hline & Control & $\mathrm{Nd}$ & $1.15 \pm 0.16^{\mathrm{a}-\mathrm{e}}$ & $*$ & $*$ & & & & \\
\hline & 1-MCP & $\mathrm{Nd}$ & $\mathrm{Nd}$ & $1.52 \pm 0.87^{\mathrm{b}-\mathrm{f}}$ & $1.76 \pm 0.06^{\mathrm{d}-\mathrm{g}}$ & & & & \\
\hline \multirow{4}{*}{$\begin{array}{l}\text { FRUCTOSE (mg/g) } \\
\text { Small }\end{array}$} & $\begin{array}{l}\text { 1-MCP + } \\
\text { ethephon }\end{array}$ & $\mathrm{Nd}$ & $\mathrm{Nd}$ & $0.58 \pm 0.04^{\mathrm{a}}$ & $1.74 \pm 0.05^{\mathrm{c}-\mathrm{g}}$ & & & & \\
\hline & $<0.001$ & 0.414 & 0.401 & 0.158 & & & & & \\
\hline & Control & $\mathrm{Nd}$ & $\mathrm{Nd}$ & $0.86 \pm 0.01^{\mathrm{a}, \mathrm{b}, \mathrm{c}}$ & $*$ & & & & \\
\hline & 1-MCP & $\mathrm{Nd}$ & $\mathrm{Nd}$ & $0.32 \pm 0.01^{\mathrm{a}}$ & $0.66 \pm 0.11^{\mathrm{a}, \mathrm{b}, \mathrm{c}}$ & & & & \\
\hline \multirow{3}{*}{ Medium } & $\begin{array}{l}\text { 1-MCP + } \\
\text { ethephon }\end{array}$ & $\mathrm{Nd}$ & $\mathrm{Nd}$ & $0.36 \pm 0.07^{\mathrm{a}, \mathrm{b}}$ & $1.17 \pm 0.03^{\mathrm{a}, \mathrm{b}, \mathrm{c}}$ & & & & \\
\hline & Control & $\mathrm{Nd}$ & $0.99 \pm 0.2^{\mathrm{a}}$ & $*$ & $*$ & & & & \\
\hline & 1-MCP & $\mathrm{Nd}$ & $\mathrm{Nd}$ & $0.78 \pm 0.06^{\mathrm{a}, \mathrm{b}, \mathrm{c}}$ & $0.85 \pm 0.09^{\mathrm{a}, \mathrm{b}, \mathrm{c}}$ & & & & \\
\hline \multirow{4}{*}{ Large } & $\begin{array}{l}\text { 1-MCP + } \\
\text { ethephon }\end{array}$ & $\mathrm{Nd}$ & $\mathrm{Nd}$ & $0.69 \pm 0.03^{a, b, c}$ & $0.78 \pm 0.06^{\mathrm{a}, \mathrm{b}, \mathrm{c}}$ & & & & \\
\hline & Control & $\mathrm{Nd}$ & $0.91 \pm 0.13^{\mathrm{a}}$ & $*$ & $*$ & & & & \\
\hline & 1-MCP & $\mathrm{Nd}$ & $\mathrm{Nd}$ & $1.29 \pm 0.44^{\mathrm{a}, \mathrm{b}, \mathrm{c}}$ & $1.33 \pm 0.05^{\mathrm{a}, \mathrm{b}, \mathrm{c}}$ & & & & \\
\hline & $\begin{array}{l}\text { 1-MCP + } \\
\text { ethephon }\end{array}$ & $\mathrm{Nd}$ & $\mathrm{Nd}$ & $1.73 \pm 0.91^{\mathrm{c}}$ & $1.22 \pm 0.04^{\mathrm{a}, \mathrm{b}, \mathrm{c}}$ & & & & \\
\hline
\end{tabular}

Means with the different letter (s) within a row and column were significantly different by Duncan Multiple Range test at $p \alpha 0.05$. Each value is a mean of four replicates $(n=4) \pm$ standard error. Nd: non-detected; ${ }^{*}$ Control fruit were removed after they reached colour stage 7 (fully yellow) which indicated that they were fully ripe.

The glucose concentration of control medium $(1.26 \mathrm{mg} / \mathrm{g})$ and large $(1.15 \mathrm{mg} / \mathrm{g})$ fruit did not differ significantly, with glucose undetected in small fruit at $\mathrm{d} 10$. However, at $20 \mathrm{~d}$, control small fruit accumulated $2.87 \mathrm{mg} / \mathrm{g}$. In 1-MCP-treated fruit, large fruit had higher glucose (from 1.52 to $1.76 \mathrm{mg} / \mathrm{g}$ ) compared to small (from 0.40 to $0.86 \mathrm{mg} / \mathrm{g}$ ) and medium (from 1.02 to $1.11 \mathrm{mg} / \mathrm{g}$ ) fruit from 20 up to $30 \mathrm{~d}$ shelf-life. Small $(1.55 \mathrm{mg} / \mathrm{g}$ ) and medium $(1.74 \mathrm{mg} / \mathrm{g})$ fruit treated with ethephon $+1-\mathrm{MCP}$ did not differ significantly regarding glucose concentration; however, the medium fruit treated with ethephon +1-MCP had significantly lower glucose $(1.00 \mathrm{mg} / \mathrm{g})$. On average, large fruit treated with 1-MCP and ethephon +1-MCP had higher soluble solids compared to small and medium-sized fruit (Table 3).

\subsection{Effect of Fruit Size and 1-MCP on Starch Granules}

Figure 4 shows SEM images of starch granules in small, medium, and large fruit treated with 1-MCP and ethephon + 1-MCP during $20 \mathrm{~d}$ shelf-life. Starch granules had a smooth surface and presented an oval and elongated shape in small, medium, and large-sized fruit. During shelf-life in 1-MCP-treated medium and large fruit, granules were small and few with elongated shape compared to small fruit, which had more and bigger granules. In fact, at $20 \mathrm{~d}$, granules surface in large 1-MCP-treated fruit were wrinkled and rough. In ethephon $+1-\mathrm{MCP}$, large fruit presented few granules with wrinkled surface after $10 \mathrm{~d}$, up to $20 \mathrm{~d}$ shelf-life, compared to small- and medium-sized fruit. Small and 
medium fruit treated with ethephon + 1-MCP showed small-sized granules with wrinkled surface after $20 \mathrm{~d}$ shelf-life (Figure 4 ).
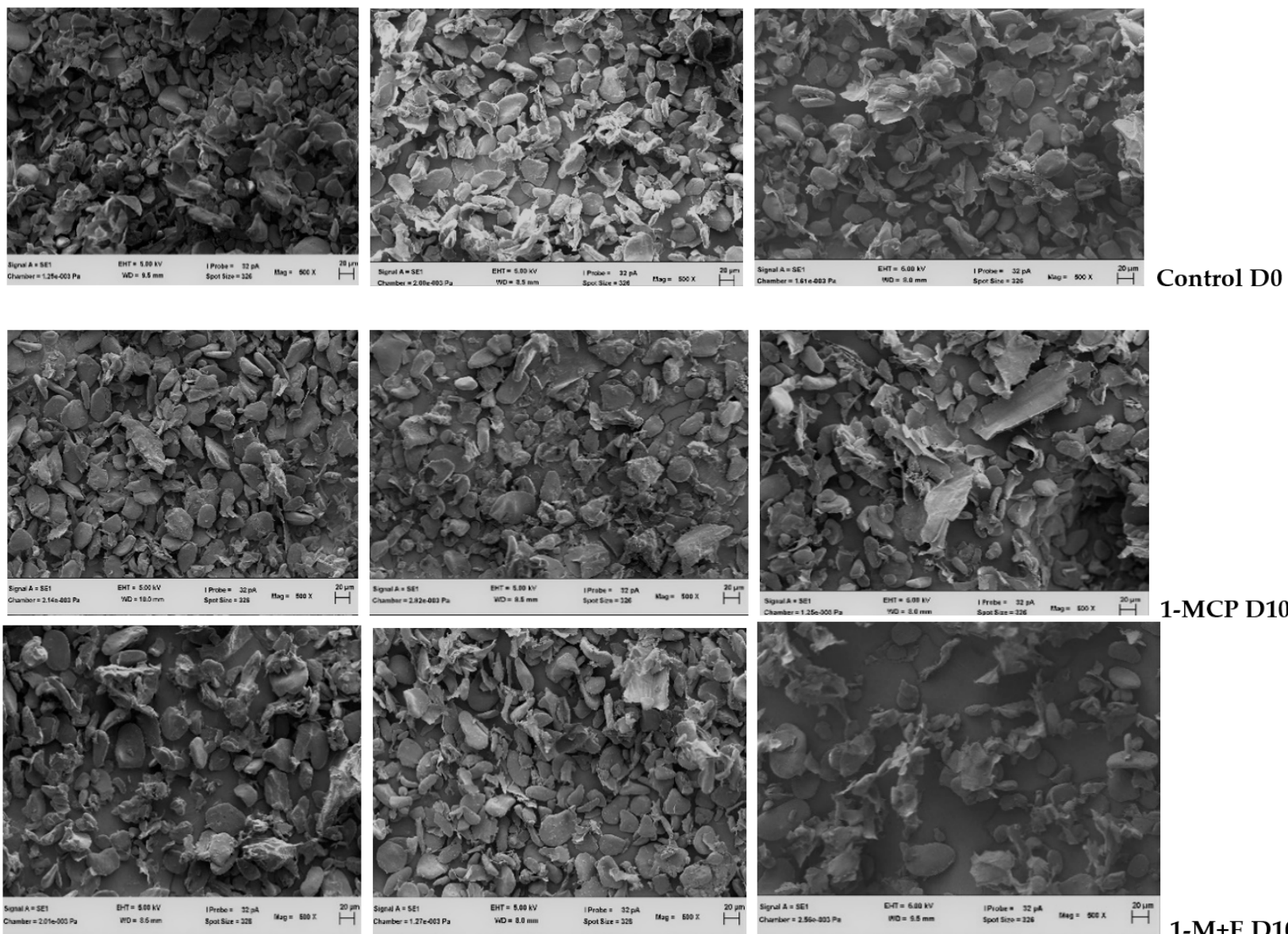

1-MCP D10
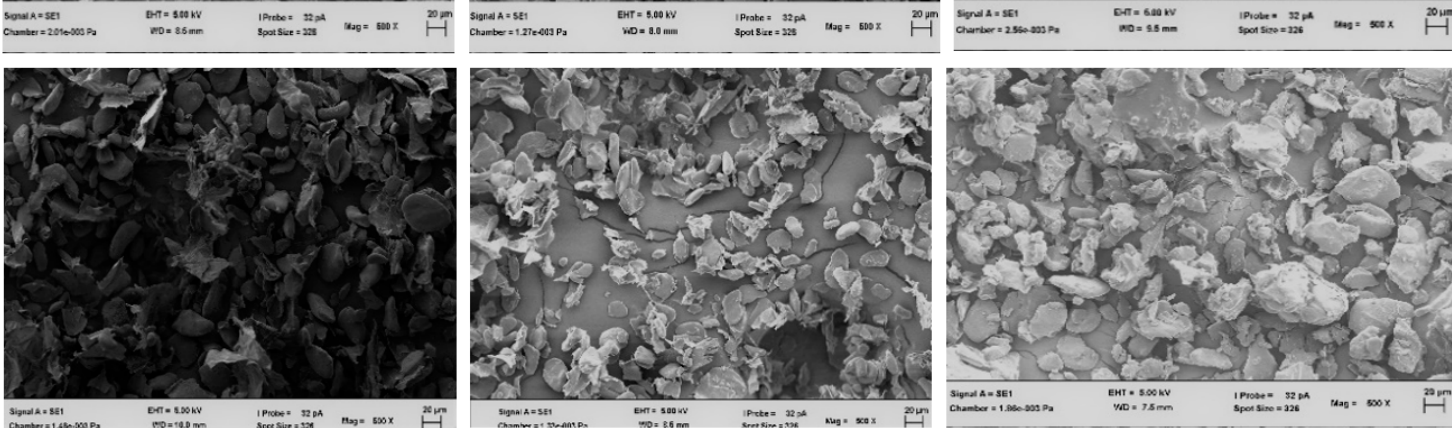

1-M+E D10
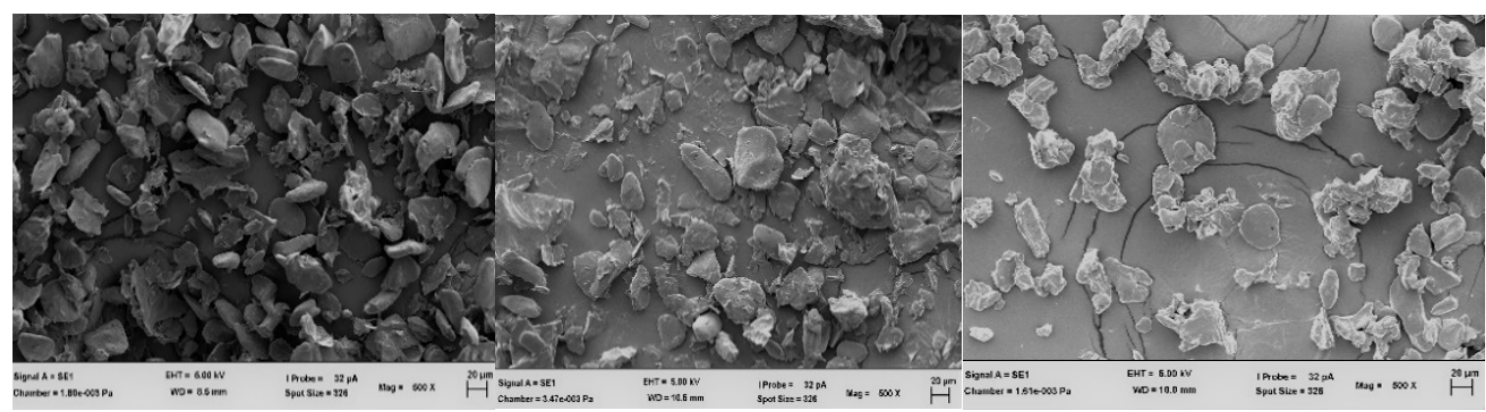

1-MCP D20

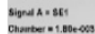

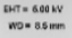

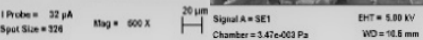

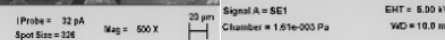

1-M+E D20

Figure 4. Scanning Electron Microscopy (SEM) images of the starch granules of small (left column), medium (middle column) and large (right column) fruit treated with 1-MCP and ethephon + 1-MCP (1-M+E) during $20 \mathrm{~d}$ shelf-life at ambient temperature. 


\section{Discussion}

The fruit in the present study were harvested at green, pre-climacteric stage; however, they differed slightly in terms of other quality parameters (Table 1). Pulp starch and sucrose concentrations were significantly higher in medium-sized compared to small and large fruit, with no significant effect on the dry matter. This suggested that dry matter content is the same in small, medium, and large fruit at harvest. The same result was reported in banana fruit [3]. However, our results differ from Jullien et al. [3], who reported that pulp starch concentration did not differ significantly between large and smaller fruit at harvest. We, therefore, evaluated starch granules at microscopic level to understand how starch concentration differed in fruit of different sizes in the present study. Our results showed that granules in small fruit were more intact than in medium and large fruit (Figure 4), suggesting granule disruption (gelatinisation), which was also indicated by higher sucrose (major soluble solid in green banana) in medium and large fruit (Table 1). Our results, therefore, demonstrate that small and medium fruit have higher starch concentrations at harvest, since starch granule disruption was not initiated compared to large fruit. The difference between our results and those reported by Jullien et al. [3] in respect of starch concentrations may probably be due to species (cultivars), since they have different structural granules which are also differently degraded [2].

The present study showed that 1-MCP and ethephon + 1-MCP, in comparison to control, extended the shelf-life of banana fruit irrespective of fruit size; however, they differed in colour change, softening, and sweetness. Medium and large fruit treated with $1-\mathrm{MCP}$ and ethephon $+1-\mathrm{MCP}$ recovered their ripening capacity earlier than the smaller fruit (Figure 1). Although there are limited reports on the effect of fruit size on 1-MCP in banana, our results are contrary to Harris et al. [14], who reported that hand within a bunch (size) did not affect 1-MCP efficacy in banana fruit. However, our findings are like those of Moradinezhad et al. [13]. The authors found that 1-MCP prolonged the shelf-life of banana fruit harvested from the top of the bunch (extra-large) compared to the bottom (small) and the difference was attributed to variation in maturity within a bunch [13]. It was also found that 1-MCP efficacy in various fruits was affected by maturity [15-17]. Our results suggest that fruit size has a significant effect on the efficacy of postharvest 1-MCP treatment in banana. This probably indicates that smaller fruit located at the lower position of the bunch are less mature compared to those at the top or middle [3]. Therefore, it is important to treat fruit of the same size with 1-MCP to prolong shelf-life and maintain quality. Small and large fruit may require less and more than $400 \mathrm{~nL} \mathrm{~L}^{-1} 1-\mathrm{MCP}$ concentration, respectively. This might be due to the number of cells, probably containing cell-wall-bound receptors, each fruit contains.

The results of the present study show that 1-MCP delayed peel yellowing in small than in medium and large fruit by maintaining higher chlorophyll (Figure 2), indicating that banana peel colour was more yellow in medium and large fruit. It was suggested that yellowing of banana peel is more related to chlorophyll degradation than carotenoids accumulation [10]. Our results agree with this hypothesis, as total carotenoids decreased with chlorophyll during peel yellowing (ripening) (Figure 2). Therefore, the reason smaller fruit treated with 1-MCP took longer to develop yellow colour, or developed irregularly, might be due to a significant difference in chlorophyll at harvest; higher chlorophyll was found in small than in medium and large fruit (Table 1). Banana peel yellowing in small fruit was more evident when ethephon $+1-\mathrm{MCP}$ treatment was used; slightly similar to medium and large fruit (Figure 1). It was also previously found that fruit treated with ethephon +1-MCP rather than 1-MCP alone developed better yellow peel colour in banana fruit [10-12]; however, the effect of fruit size or maturity (bunch position) in those studies was not evaluated. To our knowledge, this is the first report on the comparison between ethephon + 1-MCP treatment effect on small, medium, and large fruit in banana. The results suggest that the efficacy of ethephon $+1-\mathrm{MCP}$ on colour change in banana might be fruit-size independent, compared to 1-MCP alone. 
Our results show that application of 1-MCP delayed softening in large and medium fruit, compared to small fruit (Figure 3). However, this effect changed when fruit were treated with ethephon +1-MCP; softening was almost similar in all the fruit. Application of ethephon +1-MCP in banana fruit resulted in the activity of softening-related enzymes increasing significantly compared to 1-MCP [11]. Therefore, our results indicate that ethephon +1-MCP allows more softening in fruit of all sizes than 1-MCP. Moreover, the results suggest that $1-\mathrm{MCP}$ delays softening more in medium and large than in small fruit. 1-MCP maintains higher firmness in various fruits [7], and the effect appears to be strong in less mature fruit $[17,23,24]$. Therefore, it is unclear why, in the present study, small fruit (less mature) treated with 1-MCP were softer compared to medium and larger fruit. A plausible explanation is that small fruit probably have large cells with bigger interspaces [3], hence they lost more water compared to other treated fruits (Figure 3). Firmer fruit tend to have smaller cell walls with few interspaces [25]. In bell pepper, more firmness and moisture were lost in small than large fruit; the difference was attributed to the surface area to fresh mass ratio, which was higher in smaller fruit [26]. Similar results were reported in banana [27].

Starch accumulates during growth and development and degrades at ripening stages in banana fruit [2-4]. Starch degradation leads to an increase in sucrose, glucose, and fructose, which are responsible for fruit sweetness and providing energy for other metabolic processes: peel colour change, pulp softening, etc. [2]. Our results show that in comparison to control, 1-MCP and ethephon + 1-MCP maintained higher starch concentrations, indicating that carbohydrate catabolism and other energy-demanding processes were delayed. These results are in accordance with those of do Nascimento et al. [4] and Mainardi et al. [28], who reported that 1-MCP reduced starch degradation in banana fruit. Soluble solids were lower in small than medium and large fruit treated with 1-MCP, suggesting that carbohydrate catabolism in 1-MCP-treated banana differs with size of fruit. 1-MCP delays starch degradation in banana fruit by inhibiting the activities of starch-degrading enzymes, including alpha and beta-amylose $[2,5]$.

Another reason carbohydrate metabolism was delayed in 1-MCP treated fruit is probably the decreased respiration rate in the fruit [29], suggesting the ripening rate was low in 1-MCP-treated small fruit. Respiration rate (carbon dioxide) and ethylene are important physiological variables used to measure ripening rate in climacteric fruits such as banana. The increase in these gases was concomitant with starch degradation in banana fruit $[4,28]$. Therefore, based on our results (Tables 2 and 3), it is plausible to assume that carbon dioxide and ethylene production were higher in medium and large than in small fruit treated with 1-MCP. This might explain why medium and large fruit recovered their ripening capacity earlier compared to small fruit, especially regarding colour change. 1-MCP-treated fruit recover their ripening capacity by synthesising new ethylene receptors $[7-9,30]$. However, it remains to be seen what causes the receptor to be re-synthesised post 1-MCP treatment. Starch concentration is known to play an important role in softening and colour change processes [2,5]; however, there are limited reports linking it to receptor biosynthesis in 1-MCP-treated banana fruit post treatment. Therefore, it would be interesting to investigate whether ethylene gene expression (or receptor turnover) post 1-MCP treatment in fruit of different sizes in banana depends on the starch concentration at harvest.

In the present study, we hypothesised that banana fruit within a bunch differs in size and carbohydrate composition, and that fruit with high starch would ripen or develop a uniform yellow colour better post 1-MCP treatment. Our results seem inconsistent and therefore do not confirm the hypothesis. For instance, small fruit had higher starch than large at harvest but failed to ripen uniformly in terms of colour change, whilst medium fruit had higher starch than small and large and developed a better yellow colour. In addition, large fruit had a lower starch concentration than small and medium and developed a better yellow colour. Although it seems medium fruit had enough energy to recover from 1-MCP treatment, the same was not the case for large fruit. We assume that, in the present study, 
large fruit were more mature than other fruits prior to 1-MCP treatment, and therefore quick and uniform recovery could be related to higher ethylene [31] than starch in the fruit. In small fruit treated with 1-MCP, higher starch concentration seemed to be more responsible for softening than yellowing. This suggested that 1-MCP-treated small fruit would have a peel and pulp ripening desynchronisation.

Based on starch granules analysis, our results show for the first time that granules in small fruit were intact compared to medium- and large-sized fruit (Figure 4.). In addition, granules changed from an oval shape with a smooth surface to a more elongated shape with wrinkled and rough surfaces in medium and large fruit, treated with both 1-MCP and ethephon $+1-\mathrm{MCP}$, than in small fruit. This change in granule morphology probably indicated degradation, which is initiated by various enzymes during fruit ripening $[2,5]$. Small fruit have many cells with reduced assimilates compared to larger fruit [6]. Therefore, it is possible that many cells observed in 1-MCP-treated small fruit were empty. Moreover, small granules are more susceptible to enzymatic actions compared to large ones [2], which might explain why granules in medium and large fruit treated with 1-MCP and ethephon + 1-MCP decreased in number by more than in small fruit (Figure 4).

\section{Conclusions}

Postharvest application of 1-MCP on a banana to prolong fruit shelf-life and maintain quality is inconsistent, possibly due to fruit of different size and maturity in a consignment. Therefore, the effect of fruit size on 1-MCP efficacy was investigated. Our results demonstrated that 1-MCP and ethephon + 1-MCP extend the shelf-life of small, medium, and large fruit in comparison to control fruit. However, the ripening recovery post treatment differed based on the fruit size. Small fruit treated with 1-MCP alone recovered their ripening capacity later and more unevenly than medium and large fruit. With respect to ethephon + 1-MCP, fruit size appears to have little effect, although the peel of medium and large fruit was more yellow compared to small fruit. Overall, our results demonstrate that fruit size affects 1-MCP efficacy in banana, and this might explain the inconsistency of the treatment in the fruit. Moreover, 1-MCP + ethephon treatment allowed for recovery of ripening capacity, irrespective of size, suggesting that it is a beneficial treatment. Uneven ripening recovery in small fruit treated with $1-\mathrm{MCP}$ suggests that $400 \mathrm{~nL} \mathrm{~L}^{-1} 1-\mathrm{MCP}$ concentration was strong for receptors. Therefore, further studies are required to optimise 1-MCP concentration based on fruit size. In addition, further studies can be conducted to understand whether fruit reserves (starch) influence ethylene gene expression and thus ripening recovery in 1-MCP-treated banana fruit.

Author Contributions: Conceptualisation, T.K.S. and L.S.M.; methodology, T.K.S.; validation, T.K.S.; formal analysis, T.K.S.; investigation, T.K.S.; resources, L.S.M.; data curation, T.K.S.; writing—original draft preparation, T.K.S.; writing-review and editing, T.K.S. and L.S.M.; visualisation, T.K.S.; supervision, L.S.M.; project administration, L.S.M.; funding acquisition, L.S.M. All authors have read and agreed to the published version of the manuscript.

Funding: This research received no external funding.

Institutional Review Board Statement: Not applicable.

Informed Consent Statement: Not applicable.

Data Availability Statement: Not applicable.

Acknowledgments: The Agricultural Research Council (ARC) is greatly acknowledged.

Conflicts of Interest: The authors declare no conflict of interest. 


\section{References}

1. Anyasi, T.A.; Jideani, A.I.; Mchau, G.R. Functional properties and postharvest utilization of commercial and noncommercial banana cultivars. Compr. Rev. Food Sci. Food Saf. 2013, 12, 509-522. [CrossRef]

2. Cordenunsi-Lysenko, B.R.; Nascimento, J.R.O.; Castro-Alves, V.C.; Purgatto, E.; Fabi, J.P.; Peroni-Okyta, F.H.G. The starch is (not) just another brick in the wall: The primary metabolism of sugars during banana ripening. Front. Plant Sci. 2019, 10, 391. [CrossRef]

3. Jullien, A.; Malézieux, E.; Michaux-Ferrière, N.; Chillet, M.; Ney, B. Within-bunch variability in banana fruit weight: Importance of developmental lag between fruits. Ann. Bot. 2001, 87, 101-108. [CrossRef]

4. do Nascimento, J.R.O.; Júnior, A.V.; Bassinello, P.Z.; Cordenunsi, B.R.; Mainardi, J.A.; Purgatto, E.; Lajolo, F.M. Beta-amylase expression and starch degradation during banana ripening. Postharvest Biol. Technol. 2006, 40, 41-47. [CrossRef]

5. Xiao, Y.y.; Kuang, J.f.; Qi, X.n.; Ye, Y.j.; Wu, Z.X.; Chen, J.y.; Lu, W.j. A comprehensive investigation of starch degradation process and identification of a transcriptional activator Mab HLH 6 during banana fruit ripening. Plant Biotechnol. J. 2018, 16, 151-164. [CrossRef] [PubMed]

6. Jullien, A.; Munier-Jolain, N.G.; Malézieux, E.; Chillet, M.; Ney, B. Effect of pulp cell number and assimilate availability on dry matter accumulation rate in a banana fruit [Musa sp. AAA group 'Grande Naine' (Cavendish subgroup)]. Ann. Bot. 2001, 88, 321-330. [CrossRef]

7. Watkins, C.B. The use of 1-methylcyclopropene (1-MCP) on fruits and vegetables. Biotechnol. Adv. 2006, 24, 389-409. [CrossRef]

8. Sisler, E.C.; Grichko, V.P.; Serek, M. Interaction of ethylene and other compounds with the ethylene receptor: Agonists and antagonists. In Ethylene Action in Plants; Springer: Berlin/Heidelberg, Germany, 2006; pp. 1-34.

9. Sisler, E.C.; Serek, M. Inhibitors of ethylene responses in plants at the receptor level: Recent developments. Physiol. Plant. 1997, 100, 577-582. [CrossRef]

10. Satekge, T.K.; Magwaza, L.S. The Combined Effect of 1-methylcyclopropene (1-MCP) and Ethylene on Green-life and Postharvest Quality of Banana Fruit. Int. J. Fruit Sci. 2020, 1-13. [CrossRef]

11. Zhu, X.; Shen, L.; Fu, D.; Si, Z.; Wu, B.; Chen, W.; Li, X. Effects of the combination treatment of 1-MCP and ethylene on the ripening of harvested banana fruit. Postharvest Biol. Technol. 2015, 107, 23-32. [CrossRef]

12. Botondi, R.; De Sanctis, F.; Bartoloni, S.; Mencarelli, F. Simultaneous application of ethylene and 1-MCP affects banana ripening features during storage. J. Sci. Food Agric. 2014, 94, 2170-2178. [CrossRef]

13. Moradinezhad, F.; Sedgley, M.; Klieber, A.; Able, A. Variability of responses to 1-methylcyclopropene by banana: Influence of time of year at harvest and fruit position in the bunch. Ann. Appl. Biol. 2008, 152, 223-234. [CrossRef]

14. Harris, D.; Seberry, J.; Wills, R.; Spohr, L. Effect of fruit maturity on efficiency of 1-methylcyclopropene to delay the ripening of bananas. Postharvest Biol. Technol. 2000, 20, 303-308. [CrossRef]

15. Pereira, M.E.C.; Sargent, S.A.; Sims, C.A.; Huber, D.J.; Crane, J.H.; Brecht, J.K. Ripening and sensory analysis of GuatemalanWest Indian hybrid avocado following ethylene pretreatment and/or exposure to gaseous or aqueous 1-methylcyclopropene. Postharvest Biol. Technol. 2014, 92, 121-127. [CrossRef]

16. Wang, Y.; Sugar, D. 1-MCP efficacy in extending storage life of 'Bartlett' pears is affected by harvest maturity, production elevation, and holding temperature during treatment delay. Postharvest Biol. Technol. 2015, 103, 1-8. [CrossRef]

17. Chiriboga, M.A.; Schotsmans, W.C.; Larrigaudière, C.; Dupille, E.; Recasens, I. Responsiveness of 'Conference' pears to 1methylcyclopropene: The role of harvest date, orchard location and year. J. Sci. Food Agric. 2013, 93, 619-625. [CrossRef] [PubMed]

18. Blankenship, S.M.; Dole, J.M. 1-Methylcyclopropene: A review. Postharvest Biol. Technol. 2003, 28, 1-25. [CrossRef]

19. Deng, L.; Jiang, C.-Z.; Mu, W.; Wang, Q. Influence of 1-MCP treatments on eating quality and consumer preferences of 'Qinmei' kiwifruit during shelf life. J. Food Sci. Technol. 2015, 52, 335-342. [CrossRef]

20. Lichtenthaler, H.K.; Buschmann, C. Chlorophylls and carotenoids: Measurement and characterization by UV-VIS spectroscopy. Curr. Protoc. Food Anal. Chem. 2001, 1, F4. 3.1-F4. 3.8. [CrossRef]

21. Lo'ay, A.; El-Khateeb, A. Impact of exogenous pyridoxin treatments of 'Williams' banana on the activities of starch degrading enzymes. Sci. Hortic. 2019, 243, 48-54. [CrossRef]

22. Ncama, K.; Tesfay, S.Z.; Fawole, O.A.; Opara, U.L.; Magwaza, L.S. Non-destructive prediction of 'Marsh' grapefruit susceptibility to postharvest rind pitting disorder using reflectance Vis/NIR spectroscopy. Sci. Hortic. 2018, 231, 265-271. [CrossRef]

23. Gamrasni, D.; Ben-Arie, R.; Goldway, M. 1-Methylcyclopropene (1-MCP) application to Spadona pears at different stages of ripening to maximize fruit quality after storage. Postharvest Biol. Technol. 2010, 58, 104-112. [CrossRef]

24. Villalobos-Acuna, M.G.; Biasi, W.V.; Flores, S.; Jiang, C.-Z.; Reid, M.S.; Willits, N.H.; Mitcham, E.J. Effect of maturity and cold storage on ethylene biosynthesis and ripening in 'Bartlett' pears treated after harvest with 1-MCP. Postharvest Biol. Technol. 2011, 59, 1-9. [CrossRef]

25. Johnston, J.W.; Hewett, E.W.; Hertog, M.L. Postharvest softening of apple (Malus domestica) fruit: A review. N. Z. J. Crop Hortic. Sci. 2002, 30, 145-160. [CrossRef]

26. Díaz-Pérez, J.C.; Muy-Rangel, M.D.; Mascorro, A.G. Fruit size and stage of ripeness affect postharvest water loss in bell pepper fruit (Capsicum annuum L.). J. Sci. Food Agric. 2007, 87, 68-73. [CrossRef]

27. Ahmad, S.; Nasir, M.A.; Anwar, Z.; Thompson, A. Effect of fruit size and temperature on the shelf life and quality of ripe banana fruit. Sarhad J. Agric. 2007, 23, 45. 
28. Mainardi, J.A.; Purgatto, E.; Vieira, A.; Bastos, W.A.; Cordenunsi, B.R.; Oliveira do Nascimento, J.R.; Lajolo, F.M. Effects of ethylene and 1-methylcyclopropene (1-MCP) on gene expression and activity profile of $\alpha$-1, 4-glucan-phosphorylase during banana ripening. J. Agric. Food Chem. 2006, 54, 7294-7299. [CrossRef]

29. Bekele, E.A.; Beshir, W.F.; Hertog, M.L.; Nicolai, B.M.; Geeraerd, A.H. Metabolic profiling reveals ethylene mediated metabolic changes and a coordinated adaptive mechanism of 'Jonagold' apple to low oxygen stress. Physiol. Plant. 2015, 155, $232-247$. [CrossRef]

30. In, B.-C.; Binder, B.M.; Falbel, T.G.; Patterson, S.E. Recovery of ethylene sensitivity and responses in carnation petals post-treatment with 1-methylcyclopropene. Postharvest Biol. Technol. 2016, 121, 78-86. [CrossRef]

31. Zhang, Z.; Huber, D.J.; Hurr, B.M.; Rao, J. Delay of tomato fruit ripening in response to 1-methylcyclopropene is influenced by internal ethylene levels. Postharvest Biol. Technol. 2009, 54, 1-8. [CrossRef] 